\title{
Northern Exposure: Promoting Arctic Science News to the Canadian Public
}

\author{
by Ruth Klinkhammer
}

\section{INTRODUCTION}

$\mathrm{I}$ N 2008, the Arctic Institute won an International Polar Year (IPY) grant, through Indian and Northern Affairs Canada, to promote Arctic science to Canadians. The award was timely for a number of reasons.

For one, the Arctic is currently the focus of much public attention because of the obvious and massive impact of climate change. In the past decade, sea ice has broken extent minimums three times. Scientists suspect that some polar bear populations are in danger because of lost habitat. Warming temperatures are causing vegetation changes on mountain slopes and on tundra. Anyone at all familiar with the Arctic knows this list could go on.

In addition, more attention is currently being paid to the endeavor of communicating science to the public. Governments, scientists, and communication professionals are all making an increased effort to present research results to the public - albeit for very different reasons. There's even a small but growing cadre of journalists dedicated to science news.

And of course, the Arctic science promotion program falls at the end of the fourth IPY, when many science projects are beginning to return results.

Yet the landscape is not without its valleys. Layoffs are gutting newsrooms in Canada and the United States, and science reporters are among the first casualties. Some evidence shows the public's interest in science is waning. Traditional media are losing audiences to non-traditional sources such as websites, blogs, and other forms of social media. This paper will offer a short discussion of the Arctic Institute's IPY project in the context of the wider movement to promote and publicize science.

\section{IPY Project}

In 2007, Indian and Northern Affairs Canada (INAC) announced that it had set aside $\$ 5$ million for communication, outreach, and training projects. The objectives of the INAC program are to raise awareness of the Canadian Arctic and northern issues, create dialogue and build connections between northern and southern regions of Canada, promote IPY, engage children and youth in polar science, and provide research training to Northerners.
The Arctic Institute's project promotes Arctic science stories to Canadians through the news media. Working with the editors of national and international journals, the project manager selects articles that might attract media attention. Authors are then interviewed, and media releases are written and distributed across Canada. So far, the project has been particularly successful with news media in the North, which have picked up close to $50 \%$ of the releases issued.

\section{Defining News}

A glance at the communication departments of research institutes and universities shows they are populated largely by former journalists. Despite the fact that most journalists do not have any scientific background, there are sound reasons for this hiring practice. Not only can journalists write quickly and to deadline, but they also know what editors want and understand the deadline-driven industry. They know a good story when they see one, and they know how to package it for public consumption.

There are several values or characteristics that editors and journalists use, consciously or unconsciously, to determine if an event or idea warrants coverage (Cumming and McKercher, 1994). These are, in no particular order, impact (how large was the event?), timeliness (is it new?), prominence (are the people involved well-known?), proximity (how close is the event to the news audience?), bizarreness (man-bites-dog stories), conflict (controversy and clashes), currency (an issue that's gained prominence), and human interest (stories with an entertainment factor). These values are used to judge whether a story is hard news, but they also come into play for science news. For instance, one narwhal trapped under ice in a bay might be news in a small northern newspaper (proximity), but 600 trapped narwhals could become national news (impact, bizarreness), and 600 narwhals trapped in ice because of the impact of climate change might become international news (impact, bizarreness, and currency)-especially if there is a polar bear angle (currency).

What the public wants also determines, to some extent, what the media look for. In order to keep audiences, newspapers and the broadcast media must cater to their readership. This does not mean that the media focus only on what they believe audiences want. Not to put too noble a spin on 


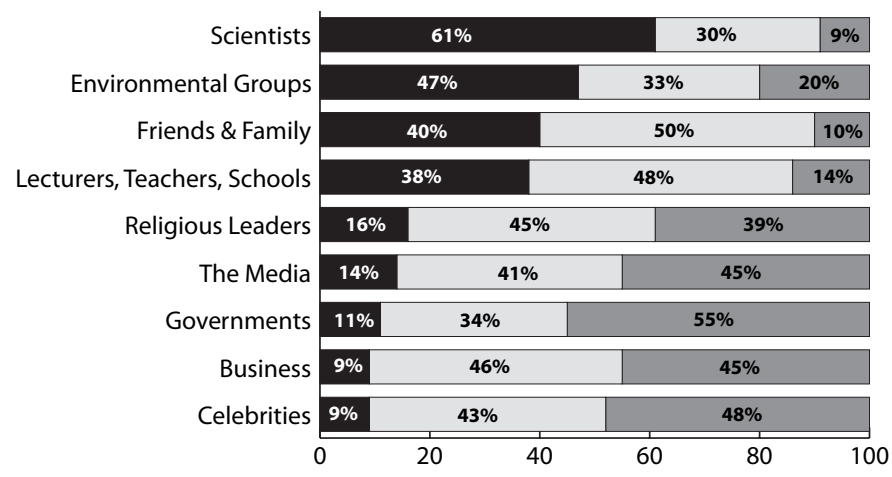

Trust

Neither trust nor mistrust

Mistrust

FIG. 1. Level of trust in sources of information on climate change, based on a survey of 2734 citizens of the United Kingdom and the United States (AccountAbility, 2007:23). Reprinted with permission from AccountAbility, London.

it, editors and journalists still believe citizens need to know certain things in order to make informed decisions.

So what does the public want in terms of science news? Is anyone even interested in science news?

\section{Public Interest in Science}

There are mixed statistics on whether the public wants science news. A 2007 poll conducted by Angus Reid for Research Canada, a not-for-profit organization working to build support for health research in Canada, showed that Canadians want more coverage of science and health issues (Worton, 2007). The survey also showed that when it comes to health issues, Canadians trust scientists as a source of information. These results on levels of trust are similar to findings of an AccountAbility/Consumers International survey (2007), administered to 2734 citizens of the United Kingdom and the United States. Figure 1 shows that $61 \%$ of people polled cited scientists as a trusted source of information about climate change, compared to $14 \%$ for media, $11 \%$ for government, and $9 \%$ for business.

However, a 2008 news consumption survey of U.S. citizens by the Pew Research Center found that while the public's news interests have been relatively stable since 2002, few of the people polled look for science news. Table 1 shows that people most want news of the weather, followed by crime news. Science news interest sits at a low 13\%, a figure that has been dropping over the past six years. There is evidence that when people tune into weather, they do receive some science news. Over half of 217 weathercasters surveyed in a U.S. study said they have been reporting on global climate change (Wilson, 2008). Weathercasters also report that station managers are asking them to comment on other science topics, including "astronomy, biodiversity, cloning, cosmology, physics, geography, medicine and even plate tectonics and volcanism" (Wilson, 2008:74).

When they do look for science news, audiences seek out the strange. It is the perception of editors that audiences
TABLE 1 . Types of news followed closely (\% of people surveyed) in the United States, 2002 to $2008 .{ }^{1}$

\begin{tabular}{lcccc}
\hline \hline Type of News & 2002 & 2003 & 2006 & 2008 \\
\hline Weather & - & 53 & 50 & 48 \\
Crime & 30 & 32 & 29 & 28 \\
Environment & - & - & - & 21 \\
National Politics & 21 & 24 & 17 & 21 \\
Health & 26 & 26 & 24 & 20 \\
Sports & 25 & 25 & 23 & 20 \\
Religion & 19 & 20 & 16 & 17 \\
Science and Technology & 17 & 16 & 15 & 13 \\
Entertainment & 14 & 15 & 12 & 10 \\
\hline \hline
\end{tabular}

${ }^{1}$ (Pew Research Center, 2008:39).

want science news that focuses on "sex and freaks" (Black, 2007). In other words, they want the silly, the crazy, the obscure, and the downright bizarre.

A glance at a few websites demonstrates that this is often what they get. For instance, the most popular headlines on the British Broadcasting Corporation's science and environment page for February 16 to 20, 2009 were: "Grizzlies reveal "fancy footwork," "Race for 'God particle' heats up," and "Stem cell 'cure' boy gets cancer." The Australian Broadcasting Corporation runs an excellent science website with numerous interactive features. Users are invited to post photos, blog, and pose questions to scientific experts. There are audio clips to listen to, videos to watch, quizzes to take and podcasts to download. Yet, the science news on this site often borders on the bizarre. "Body painting helps anatomy lessons," "Telescope spots biggest gamma-ray blast," and "Can love change the way you smell?" are just a few of the articles posted to titillate and attract readers. Often the science pages of news websites read more like headlines in supermarket tabloids than like serious journalism.

This "let's make science fun" attitude in part reflects an attempt to counter the image of the scientist as a boring, white-coated, anti-social geek buried in a lab. But the danger of this approach is that it often frames scientists as sources who are reporting on one new problem or one new finding. Science is not covered as an ongoing story or from a wider frame. Instead, the story is covered as a particular episode. One impact of this approach on science reporting is that the voice of science fades from the discussion when politicians and administrators turn to developing policies and guidelines. The scientists, having reported their research results, are forgotten.

\section{FRAMING SCIENCE}

A frame is an angle or device used by individuals to organize facts in a way that makes sense. Journalists, consciously or unconsciously, use frames to organize facts into a comprehensive body that tells a story from a specific, culturally prescribed perspective. According to Robert Entman, frames have particular uses: they tell us what the problem is, what the cause is, and how it can be fixed. Frames, 
according to Entman (1993:52), "select some aspects of a perceived reality and make them more salient in a communicating text, in such a way as to promote a particular problem definition, causal interpretation, moral evaluation and/ or treatment recommendation for the item described." For instance, the Arctic climate change frame highlights certain events as problems (the melting Arctic ice cap), suggests causal agents (rising greenhouse gas emissions), offers moral judgments (Alberta's "dirty" oil sands), and recommends particular solutions (carbon capture and storage).

Research on climate change news shows that scientists are most often cited as sources in stories that define problems and diagnose causes. Craig Trumbo, in his analysis of a decade of climate change stories from the mid-1980s to the mid-1990s, found that when the concept of climate change was relatively new, scientists served as sources to help define the problem and possible causes. However, as the issue of climate change matured, emphasis shifted away from "a presentation of the issue in terms of its causes and problematic nature and toward a presentation more grounded in political debate and the proposal of solutions" (Trumbo, 1996:281). As this shift occurred, politicians and special interest groups, not scientists, ascended as dominant news sources. Observes Trumbo, "The most alarming aspect of the results of this study is that, relatively speaking, scientists left the debate as it heated up."

Although coverage of the issue of climate change was declining at the time when Trumbo concluded his analysis, it did not disappear from the news. The media continue to be interested in global warming stories and, in fact, it is easier to sell an Arctic science idea if it contains a climate change angle. Further study is needed to determine what role scientists now play in news stories about climate change. In the context of the IPY Arctic science project, scientists identify and define problems when they discuss their research in media releases. They do not venture into the realm of moralizing about causes or solutions, and they rarely propose particular solutions, unless they are involved in developing them.

\section{CONCLUSION}

The role of the IPY project is not to position scientists as activists and spokespeople who are for or against specific technologies or specific research. The project's goal is to promote and publicize the science being done in the Arctic, and this objective is even more important now that IPY is winding down. Although IPY research results are just starting to come in, already they have shown that the Arctic is changing at a rate previously unimagined and have made it clear that changes in the Arctic will affect the rest of the world. As a recently issued report on the state of polar science points out, "Humankind's future environment, well-being and sustainable development require that we comprehensively understand and observe polar systems and processes and the changes that are already upon us" (Allison et al., 2009:12). Promoting Arctic science has vaulted to a new level of importance.

The media are notoriously fickle. Issues are popular as news items for only so long, and then interest shifts to a new topic. IPY helped focus media attention on the North, and much Arctic research has been well covered in Canada. The danger, as the two-year IPY period draws to a close, is that journalists will begin to look elsewhere for the next big story. One mission of the Arctic Institute project, then, is to ensure that Arctic research stays on the media's radar screen.

But the power of science promotion should not be overstated. The overall goal of the Institute's IPY Arctic Science project is to increase the public's understanding of Arctic science. But publishing stories does not mean that people will read them. And even if they do, increased knowledge of Arctic science will not necessarily mean that public support for Arctic research will increase. The jury is still out on whether there is a link between the public's understanding of science and public support for innovations in science and technology.

Nevertheless, there are positive spinoffs for the scientists whose research is featured in media releases. For one, funding agencies are happy when the scientists they support are featured in news articles. Positive publicity can also help promote a researcher's reputation with administrators on campus. Research publicity helps an institution in many ways. It can draw more research dollars, it can attract top students, and it can make the institution more appealing to world-class researchers. University administrators are apt to look favorably on scientists who attract positive media attention, and this might make it easier for researchers to find administrative support and resources.

And finally, publicizing research is a public good. The North is transforming at a rate humans have not previously witnessed. The need for Arctic research is, perhaps, more important now than ever before. Attracting the attention of other researchers, university administrators, politicians, and the public to the critical work being conducted is a necessity if support for research and education is to be developed and maintained.

\section{REFERENCES}

AccountAbility. 2007. What assures consumers on climate change? Switching on citizen power. AccountAbility/Consumers International Report. London.

Allison, I., Béland, M., Alverson, K., Bell, R., Carlson, D., Cutler, P., Danell, K., et al. 2009. The state of polar research: A statement from the International Council for Science/ World Meteorological Organization Joint Committee for the International Polar Year 2007-2008. World Meteorological Organization. 12 p. http://www.ipy.org/index.php?/ipy/detail/ state_of_polar_research/

Black, R. 2007. What people want. Presentation at Future Directions in Science Journalism Conference, 9-10 November 
2007, Peter Wall Institute for Advanced Studies, University of British Columbia.

Cumming, C., and McKercher C. 1994. The Canadian Reporter: News writing and reporting. Toronto: Harcourt, Brace and Co.

Entman, R. 1993. Framing: Toward clarification of a fractured paradigm. Journal of Communication 43:51-58.

Pew Research Center. 2008. Audience segments in a changing news environment: Key news audiences now blend online and traditional sources. Pew Research Center Biennial News Consumption Survey. Washington, D.C.: The Pew Research Center.
Trumbo, C. 1996. Constructing climate change: Claims and frames in US news coverage of an environmental issue. Public Understanding of Science 5:269-283.

Wilson, K. 2008. Television weathercasters as science communicators. Public Understanding of Science 17:73-87.

Worton, R. 2007. Communicating health research in an era of headline news. Presentation of Angus Reid Omnibus Poll results to Media Science Forum. Ottawa: Ottawa Congress Centre. http://www.rc-rc.ca/en/content.php?doc $=86 \&$ xwm $=$ true

Ruth Klinkhammer is Director of Communications at the Arctic Institute of North America. 